\title{
Residual Effect of Nutrient Management Practices in Hybrid Rice under Sri on Growth and Yield of Greengram (Vigna radiata L.) in Rice-greengram Cropping System
}

\author{
A. C. Dash ${ }^{1 *}$, B. K. Saren ${ }^{2}$ and P. K. Roul ${ }^{3}$

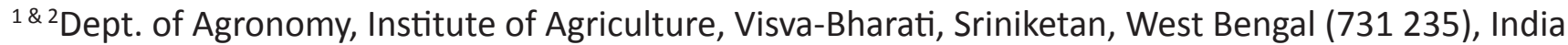 \\ ${ }^{3}$ OUAT, Bhubaneswar, Odisha (751 003), India
}

\section{Corresponding Author}

A. C. Dash

e-mail: acdashouat@gmail.com

\author{
Article History \\ Article ID: AR1846a \\ Received in $17^{\text {th }}$ September, 2017 \\ Received in revised form $16^{\text {th }}$ November, 2017 \\ Accepted in final form $5^{\text {th }}$ December, 2017
}

\begin{abstract}
The field experiments were conducted to study the residual effect of nutrient management practices of kharif rice on growth and yield of rabi greengram was conducted at Krishi Vigyan Kendra, Balasore Odisha during rabi 2013-14 and 2014-15. The experiment was laid out in RBD during the kharif season with 12 treatments replicated thrice and rabi greengram was grown in the residual fertility in the plots without disturbing the layout. The residual effect of different nutrient management prcatices applied to kharif rice significantly influenced the growth, yield attributes and yield of rabi greengram. Growth attributes viz. Plant height, number of branches, dry matter accumulation and number of nodules per plant showed significant improvement due to combined application of nutrients from organic and inorganic sources. Application of $75 \% \mathrm{~N}$ through chemical fertilizers along with $25 \% \mathrm{~N}$ through vermicompost to preceding kharif rice had significant residual effect on rabi grrengram and recorded significantly higher seed yield $\left(959 \mathrm{~kg} \mathrm{ha}^{-1}\right)$ and stover yield $\left(2753 \mathrm{~kg} \mathrm{ha}^{-1}\right)$.
\end{abstract}

Keywords: Nutrient management, residual effect, growth, yield, greengram

\section{Introduction}

Rice-pulse is one of the important cropping systems practiced in India. The cropping sequence of rice-pulse is practically feasible, viable, economical, eco-friendly, water saving technology for sustaining soil fertility and rice productivity. Awareness about crop quality and soil health increased the attention of people towards organic farming (Alagappan and Venkitaswamy, 2016). Use of chemical fertilizers alone may not keep pace with time in maintenance of soil health for sustaining the productivity. It is widely recognized that neither use of organic manures alone nor chemical fertilizers can achieve the sustainability of the yield under the modern intensive farming. The escalating costs of fertilizers on one hand and undesirable effects on soil properties on the other hand have led to inclusion of organic manures in cultivation of crops (Rama Lakshmi et al., 2014). Hence, balanced use of nutrients through organic sources like farmyard manure, vermicompost, neem cake and biofertilizers are prerequisites to sustain soil fertility, to produce maximum crop yield with optimum input level and it also leaves behind sufficient residual effect for the sequence crops (Dahiphale, 2003).

Among rice-pulse cropping systems, rice-greengram cropping system is the most important cropping system in vogue in
Odisha (Mohanty et al., 2015). At present, studies on nutrient utilization in cropping system of different crops are available but, residual effect different nutrient management practices applied to hybrid rice grown under SRI on the performance of succeeding greengram with respect to growth and yield is very meagre. Hence, the present study was undertaken.

\section{Materials and Methods}

A field experiment was conducted at Instructional Farm of Krishi Vigyan Kendra (OUAT), Baliapal, Balasore which lies in North Eastern Coastal Plain Zone of Odisha. The experiment was conducted for two years during rabi season of 2013-14 and 2014-15 to study the residual effect of various nutrient management practices applied to kharif hybrid rice grown under SRI on growth and yield of greengram. The soil of experimental site was sandy loam, slightly acidic in reaction (pH 6.7), low in organic carbon (0.36\%), available N $(232.4 \mathrm{~kg}$ $\left.\mathrm{ha}^{-1}\right)$, medium in available $\mathrm{P}\left(32.3 \mathrm{~kg} \mathrm{ha}^{-1}\right)$ available $\mathrm{K}(180.2$ $\mathrm{kg} \mathrm{ha}^{-1}$ ) and EC $0.20 \mathrm{dSm}^{-1}$. Treatments applied to preceding kharif rice crop were $\mathrm{T}_{1}$ (No nitrogen); $\mathrm{T}_{2}$ ( $50 \%$ recommended dose of $\mathrm{N}$ through fertilizers i.e. $50 \%$ RDFN); $\mathrm{T}_{3}$ (75\% RDFN); $\mathrm{T}_{4}\left(100 \%\right.$ RDFN); $\mathrm{T}_{5}$ (75\% RDFN+25\% $\mathrm{N}$ through FYM); $\mathrm{T}_{6}$ (75\% RDFN $+25 \% \mathrm{~N}$ through vermicompost); $\mathrm{T}_{7}$ (75\% RDFN+25\% N through neem cake); $\mathrm{T}_{8}\left(75 \%\right.$ RDFN+Azospirillum @ $\left.5 \mathrm{~kg} \mathrm{ha}^{-1}\right)$; 
$\mathrm{T}_{9}$ (50\% RDFN+Azospirillum @ $\left.5 \mathrm{~kg} \mathrm{ha}^{-1}\right) ; \mathrm{T}_{10}(50 \% \mathrm{RDFN}+25 \%$ $\mathrm{N}$ through FYM+Azospirillum @ $\left.5 \mathrm{~kg} \mathrm{ha}^{-1}\right) ; \mathrm{T}_{11}(50 \% \mathrm{RDFN}+25 \%$ $\mathrm{N}$ through vermicompost+Azospirillum @ $\left.5 \mathrm{~kg} \mathrm{ha}^{-1}\right) ; \mathrm{T}_{12}(50 \%$ RDFN $+25 \% \mathrm{~N}$ through neem cake+Azospirillum @ $5 \mathrm{~kg} \mathrm{ha}^{-1}$ ). The recommended dose of $\mathrm{N}, \mathrm{P}$ and $\mathrm{K}$ applied to kharif rice was 100,50 and $50 \mathrm{~kg} \mathrm{ha}^{-1}$, respectively. Experiment was laid out in RBD and with three replications. The rabi greengram crop was grown on residual nutrients without disturbing the layout made during kharif season.

Greengram cv. IPM-02-14 was taken as the test crop for the rabi experiment. Seeds were sown with a row spacing of 25 $\mathrm{cm} @ 25 \mathrm{~kg} \mathrm{ha}^{-1}$ after harvest of rice crop. Rhizobium and PSB cultures were inoculated @ 25 g each per kg of seed before sowing. Plant to plant spacing was maintained at $10 \mathrm{~cm}$ by thinning the additional plants after 10 days of sowing. A light irrigation was provided at the time of flowering and pod filling stage. Foliar applications of 2\% DAP and $0.15 \%$ Boron was made at 40 and 50 days after sowing. Observations on growth and yield attributes were recorded periodically. The matured pods were plucked manually from the plants in net plot area for recording the plot wise economic yield. The pods were sun dried for 3-4 days and threshed manually. The seed and haulm yield were recorded plot-wise after reduction of moisture content to $10-12 \%$ and these were tabulated and analyzed as per the standard procedure.

\section{Results and Discussion}

\subsection{Plant height}

The mean data pertaining to plant height of greengram revealed that treatments applied to preceding rice crop had a positive residual effect on growth parameters like plant height of greengram. It could be seen that plant height increased with the advancement of crop age and attained the maximum at the maturity stage. Residual treatment $\mathrm{T}_{6}(75 \% \mathrm{RDNF}+25 \% \mathrm{~N}$ by vermicompost) resulted in significantly taller plants than all other treatments at all the stages of crop growth. The height was found to be lowest $(39.44 \mathrm{~cm})$ with control $\left(T_{1}\right)$ as per the pooled data (Table 1 ). The results are in conformity with those of Ghanshyam and Jat (2010)

\subsection{No. of branches plant ${ }^{-1}$}

The pooled analysis over two years data showed that the number of branches plant ${ }^{-1}$ in greengram influenced significantly by the residual effect of different treatment treatments applied to the preceding rice crop. At 30 and 45 DAS T 6 (75\% RDNF+25\% N through vermicompost recorded significantly higher number of branches plant ${ }^{-1}$ followed by $T_{7}, T_{8}, T_{5}$ and these treatments were found statistically at par. At harvest, $T_{7}$ resulted in higher number of branches plant ${ }^{-1}$ (4.49) and it was found to be at par with $T_{6}, T_{5}, T_{11}$ and $T_{12}$. Control recorded $\left(T_{1}\right)$ lowest number of branches at all the stages of crop growth. Similar results were also obtained by Mohanty et al. (2014)

Table 1: Residual effect of nutrient management practices on growth attributes of greengram (Pooled data of 2 years)

\begin{tabular}{|c|c|c|c|c|c|c|c|c|c|c|c|c|}
\hline \multirow[t]{2}{*}{ Treatments } & \multicolumn{3}{|c|}{ Plant height $(\mathrm{cm})$} & \multicolumn{3}{|c|}{$\begin{array}{l}\text { No. of primary branches } \\
\text { plant }^{-1}\end{array}$} & \multicolumn{3}{|c|}{ Leaf area index } & \multicolumn{3}{|c|}{$\begin{array}{l}\text { Dry matter accumulation } \\
\qquad\left(\mathrm{g} \mathrm{m}^{-2}\right)\end{array}$} \\
\hline & $\begin{array}{c}30 \\
\text { DAS }\end{array}$ & $\begin{array}{c}45 \\
\text { DAS }\end{array}$ & $\begin{array}{c}\text { At } \\
\text { harvest }\end{array}$ & $\begin{array}{c}30 \\
\text { DAS }\end{array}$ & $\begin{array}{c}45 \\
\text { DAS }\end{array}$ & $\begin{array}{c}\text { At } \\
\text { harvest }\end{array}$ & $\begin{array}{l}30 \\
\text { DAS }\end{array}$ & $\begin{array}{l}45 \\
\text { DAS }\end{array}$ & $\begin{array}{c}\text { At } \\
\text { harvest }\end{array}$ & $\begin{array}{l}30 \\
\text { DAS }\end{array}$ & 45 DAS & $\begin{array}{c}\text { At } \\
\text { harvest }\end{array}$ \\
\hline $\mathrm{T}_{1}$ & 15.83 & 30.80 & 39.44 & 2.30 & 3.31 & 3.64 & 0.67 & 2.12 & 1.68 & 53.86 & 205.23 & 246.33 \\
\hline $\mathrm{T}_{2}$ & 16.29 & 34.30 & 43.46 & 2.75 & 3.56 & 4.03 & 0.75 & 2.77 & 2.01 & 60.24 & 214.41 & 283.66 \\
\hline $\mathrm{T}_{3}$ & 16.54 & 36.00 & 44.47 & 3.05 & 3.48 & 3.77 & 0.80 & 3.06 & 2.21 & 63.68 & 222.33 & 300.66 \\
\hline $\mathrm{T}_{4}$ & 17.39 & 37.01 & 45.19 & 3.14 & 3.86 & 4.01 & 0.86 & 3.24 & 2.50 & 71.76 & 234.42 & 318.23 \\
\hline $\mathrm{T}_{5}$ & 17.71 & 39.63 & 47.49 & 3.14 & 4.29 & 4.30 & 0.88 & 3.49 & 2.76 & 73.08 & 247.72 & 346.64 \\
\hline $\mathrm{T}_{6}$ & 17.90 & 40.20 & 47.86 & 3.38 & 4.36 & 4.40 & 0.91 & 3.56 & 2.83 & 73.60 & 257.16 & 352.45 \\
\hline $\mathrm{T}_{7}$ & 17.32 & 37.40 & 45.49 & 3.35 & 4.25 & 4.49 & 0.84 & 3.35 & 2.65 & 66.96 & 245.00 & 340.05 \\
\hline $\mathrm{T}_{8}$ & 16.30 & 35.54 & 44.02 & 3.17 & 4.23 & 4.03 & 0.83 & 3.19 & 2.24 & 64.60 & 222.63 & 313.85 \\
\hline $\mathrm{T}_{9}$ & 16.17 & 35.07 & 43.59 & 2.96 & 4.14 & 4.02 & 0.78 & 3.08 & 2.10 & 61.72 & 218.75 & 299.23 \\
\hline $\mathrm{T}_{10}$ & 17.70 & 38.09 & 45.98 & 2.93 & 3.74 & 3.64 & 0.84 & 3.41 & 2.50 & 70.16 & 242.31 & 329.22 \\
\hline $\mathrm{T}_{11}$ & 17.59 & 38.80 & 46.49 & 3.10 & 4.10 & 4.40 & 0.86 & 3.40 & 2.57 & 69.74 & 243.66 & 329.46 \\
\hline $\mathrm{T}_{12}$ & 16.89 & 36.70 & 44.24 & 3.00 & 4.07 & 4.37 & 0.80 & 3.21 & 2.30 & 65.30 & 227.39 & 310.44 \\
\hline SEm \pm & 0.24 & 0.76 & 0.75 & 0.11 & 0.16 & 0.11 & 0.02 & 0.09 & 0.07 & 1.60 & 6.24 & 11.29 \\
\hline $\mathrm{CD}(p=0.05)$ & 0.71 & 2.23 & 2.20 & 0.32 & 0.47 & 0.32 & 0.07 & 0.27 & 0.22 & 4.69 & 18.30 & 33.10 \\
\hline
\end{tabular}

$T_{1}$ : No Nitrogen; $T_{2}: 50 \%$ RDFN; $T_{3}: 75 \%$ RDFN; $T_{4}: 100 \%$ RDFN; $T_{5}: 75 \%$ RDFN + 25\% N through FYM; $T_{6}: 75 \%$ RDFN+25\% $\mathrm{N}$ through VC; $\mathrm{T}_{7}: 75 \%$ RDFN+25\% N through NC; $\mathrm{T}_{8}: 75 \%$ RDFN+Azo; $\mathrm{T}_{9}: 50 \%$ RDFN + Azo; $\mathrm{T}_{10}: 50 \%$ RDFN+25\% N through FYM + Azo; $T_{11}: 50 \%$ RDFN + 25\% N through VC + Azo; $T_{12}: 50 \%$ RDFN+25\% N through NC+Azo 


\subsection{Leaf area index (LAI)}

The residual effect of different sources of nutrition applied in kharif rice crop exerted a significant influence on leaf area index of greengram (Table 1). The pooled data shows that the leaf area index increased as the age of crop advanced up to 45 DAS and then gradually decreased up to the harvest stage. The highest leaf area index was recorded 3.56 with $75 \%$ RDFN $+25 \% \mathrm{~N}$ through vermicompost $\left(\mathrm{T}_{6}\right)$ and with a lowest value of 2.12 under $T_{1}$. As the crop age advances 45 DAS, the leaf area index gradually decreased due to leaf senescence and at harvest $T_{6}$ recorded a highest value of 2.83 though it was found statistically at par with $\mathrm{T}_{5}$ and $\mathrm{T}_{7}$. The control treatment recorded lowest value of LAl i.e. 1.68.

\subsection{Dry matter accumulation $m^{-2}$}

Residual effect of various treatments applied to hybrid rice grown in kharif season significantly influenced the dry matter production in succeeding greengram crop grown during rabi season. The pooled data pertaining to the residual effect of rice on greengram is presented in Table 1 and it indicated that there was rapid increase in dry matter as the crop advances up to 45 DAS and after that there was gradual increase up to the maturity stage. Application of $75 \%$ RDNF $+25 \% \mathrm{~N}$ through vermicompost evinced considerable effect on greengram and produced highest dry matter at 30 DAS (73.60 $\left.\mathrm{g} \mathrm{m}^{-2}\right), 60$ DAS (257.16 $\mathrm{g} \mathrm{m}^{-2}$ and at harvest $\left(352.45 \mathrm{~g} \mathrm{~m}^{-2}\right)$. The lowest dry matter accumulation i.e. $246.33 \mathrm{~g} \mathrm{~m}^{-2}$ was recorded with control $\left(T_{1}\right)$. These results are in conformity with those of Ramesh (2014).

3.5. No. of pods plant ${ }^{-1}$

The number of pods plant ${ }^{-1}$ of greengram significantly influenced by the residual effect of nutrient management practices applied to preceding kharif rice crop. From the pooled data analysis it was observed that application of $75 \%$ RDFN $+25 \% \mathrm{~N}$ through vermicompost $\left(\mathrm{T}_{6}\right)$ showed significantly highest number of pods plant ${ }^{-1}(24.85)$ and control $\left(T_{1}\right)$ resulted in lowest number of pods plant ${ }^{-1}(17.20)$. These results are in the similar line obtained by Lavanya and Ganapathy (2011) and Sangeetha et al. (2013)

3.6. No. of seeds pod ${ }^{-1}$

The data related to number of seeds per pod are presented in Table 2 indicated that different levels of nutrient management treatments on hybrid rice has significant residual impact on the number of seeds pod $^{-1}$ in greengram. The number of seeds per pod was significantly higher with $75 \%$ RDNF $+25 \%$ $\mathrm{N}$ through vermicompost (11.68) in the pooled data. These results are in conformity with those of Singh and Gujar (2012) and Sangeetha et al. (2013).

\subsection{0 seed weight}

It is noticed from the data that the treatments applied to rice did not able to produce significant effect on 1000 seed weight of greengram. However, $T_{7}$ (75\% RDNF+25\% N through neem cake) recorded numerically higher seed weight than other treatments.

\subsection{Seed yield}

The various sources of nutrition management practices applied to hybrid rice have significant residual impact on the seed yield of succeeding greengram (Table 2). From the data, it could be observed that $\mathrm{T}_{6}(75 \%$ RDFN $+25 \% \mathrm{~N}$ through vermicompost) resulted in significantly higheer seed yield 959

Table 2: Residual effect of nutrient management practices on yield attributes and yields of greengram (Pooled data of 2 years)

\begin{tabular}{|c|c|c|c|c|c|c|}
\hline Treatments & $\begin{array}{c}\text { No. of pods } \\
\text { plant }^{-1}\end{array}$ & $\begin{array}{c}\text { No. of seeds } \\
\text { pod }^{-1}\end{array}$ & $\begin{array}{c}1000 \text { seed } \\
\text { wt. (g) }\end{array}$ & $\begin{array}{c}\text { Seed yield } \\
\left(\mathrm{kg} \mathrm{ha}^{-1}\right)\end{array}$ & $\begin{array}{l}\text { Stover yield } \\
\quad\left(\mathrm{kg} \mathrm{ha}^{-1}\right)\end{array}$ & $\begin{array}{c}\text { Harvest index } \\
(\%)\end{array}$ \\
\hline $\mathrm{T}_{1}$ & 17.20 & 8.99 & 36.33 & 575 & 1716 & 25.10 \\
\hline $\mathrm{T}_{2}$ & 19.53 & 9.69 & 36.56 & 634 & 1895 & 25.07 \\
\hline $\mathrm{T}_{3}$ & 20.59 & 10.07 & 36.67 & 702 & 2057 & 25.40 \\
\hline $\mathrm{T}_{4}$ & 21.69 & 10.80 & 36.65 & 746 & 2106 & 26.14 \\
\hline $\mathrm{T}_{5}$ & 24.30 & 11.52 & 37.12 & 808 & 2379 & 25.35 \\
\hline $\mathrm{T}_{6}$ & 24.85 & 11.68 & 37.18 & 959 & 2753 & 25.84 \\
\hline$T_{7}$ & 23.80 & 11.35 & 37.20 & 768 & 2181 & 26.05 \\
\hline $\mathrm{T}_{8}$ & 20.37 & 10.01 & 36.67 & 722 & 2132 & 25.30 \\
\hline $\mathrm{T}_{9}$ & 20.05 & 9.99 & 36.65 & 709 & 2121 & 25.05 \\
\hline $\mathrm{T}_{10}$ & 22.94 & 11.22 & 36.98 & 759 & 2169 & 25.91 \\
\hline $\mathrm{T}_{11}$ & 22.90 & 11.06 & 36.80 & 755 & 2190 & 25.62 \\
\hline $\mathrm{T}_{12}$ & 21.60 & 10.63 & 36.72 & 728 & 2158 & 25.22 \\
\hline SEm \pm & 0.68 & 0.39 & 0.95 & 30 & 75 & 1.14 \\
\hline $\operatorname{CD}(p=0.05)$ & 1.99 & 1.16 & NS & 88 & 220 & NS \\
\hline
\end{tabular}

RDFN: Recommended dose of nitrogen through fertilizer; VC: Vermicompost; NC: Neem cake; Azo: Azospirillum @ 5 kg ha-1 
$\mathrm{kg} \mathrm{ha}^{-1}$ which is $66.8 \%$ higher than the control $\left(575 \mathrm{~kg} \mathrm{ha}^{-1}\right)$. The seed yield recorded with the residual effect of $75 \%$ RDFN+25\% $\mathrm{N}$ through FYM $\left(\mathrm{T}_{5}\right)$ and $75 \% \mathrm{RDFN}+25 \% \mathrm{~N}$ through neem cake $\left(\mathrm{T}_{4}\right)$ was 808 and $768 \mathrm{~kg} \mathrm{ha}^{-1}$, respectively. Similar results were also observed by Ghanshyam and Jat (2010); Alagappan and Venkitaswamy (2015)

\subsection{Haulm yield}

The haulm yield recorded followed the similar trend as that of seed yield. From the pooled data it was observed that, in the preceding rice where $75 \% \mathrm{RDNF}+25 \% \mathrm{~N}$ through vermicompost was applied exhibited the highest haulm yield of $2753 \mathrm{~kg} \mathrm{ha}^{-1}$ and the lowest yield was observed with control (1716 kg ha-1). Similar trends were also reported by Ghanshyam and Jat (2010) and Alagappan and Venkitaswamy (2015).

\subsection{Harvest index}

The pooled analysis over two years data revealed that the harvest index was not varied significantly due to residual effect of different treatments however, highest value of harvest index was obtained with $\mathrm{T}_{7}$ (75\% RDNF+25\% N through neem cake).

\section{Conclusion}

Residual effect of different organic and inorganic sources of nutrients applied to preceding kharif rice grown under SRI had significant effect on growth, yield attributes and yield of succeeding rabi greengram in rice-greengram cropping system. Application of $75 \% \mathrm{~N}$ through chemical fertilizers along with $25 \% \mathrm{~N}$ through vermicompost to preceding kharif rice had significant residual effect on rabi greengram and resulted in significantly higher values of growth parameters, yield attributes and productivity of greengram.

\section{References}

Alagappan, S., Venkitaswamy, R., 2016. Impact of different sources of organic manures in comparison with TRRI practice, RDF and INM on growth, yield and soil enzymatic activities of rice- greengram cropping system under site-specific organic farming situation. AmericanEurasian Journal of Sustainable Agriculture 10(2), 1-8.

Alagappan, S., Venkitaswamy, R., 2015. Yield and economics of rice-green gram cropping system in relation to site- specific organic nutrient management with different sources of organic manures in comparison with RDF and INM. Australian Journal of Basic and Applied Sciences 10(1), 537-541.

Ch. S., Rama Lakshmi, P., Chandrasekhar Rao, T., Sreelatha, M., Madhavi, G., Padmaja and Rao, P.V., 2014. Cumulative and residual effects of INM of kharif rice on soil enzyme activities in rabi greengram (Vigna radiata). Legume Research 37(4), 408-414.

Dahiphale, A.V., Giri, D.G., Thakre, G.V., Giri, M.D., 2003. Effect of integrated nutrient management on yield and yield contributing parameters of scented rice. Annals of Plant Physiology 17(1), 24-26.

Ghanshyam, R.K., Jat, R.K., 2010. Productivity and soil fertility as affected by organic manures and inorganic fertilizers in greengram (Vigna radiata L.) -wheat (Triticum aestivum) system. Indian Journal of Agronomy 55(1), 16-21.

Lavanya, A., Ganapathy, M., 2011. Effect of DAP, NAA and residual effect of inorganic fertilizers and organic manures on growth and yield of greengram in rice based cropping sequence. Journal of Agricultural Technology 7(3), 599-604.

Mohanty, T.R., Roul, P.K., Maity, S.K., 2014. Response of greengram (Vigna radiata $\mathrm{L}$ ) to establishment methods and nutrient management practices in rice-greengram cropping system. Journal of Food Legumes 27(3), 210-214.

Ramesh, I.S., 2014. Effect of integrated nutrient management in rice-greengram cropping sequence under south Gujrat condition. Ph. D. Thesis submitted to Navsari Agricultural University, Navsari.

Sangeetha, S.P., Balakrishnan, A., Devasenapathy, P., 2013. Influence of organic manures on yield and quality of rice (Oryza sativa L.) and blackgram (Vigna mungo L.) in rice-blackgram cropping sequence. American Journal of Plant Sciences 4, 1151-1157.

Singh, J.K., Gujar, B., 2012. Effect of biofertilizers and fertility levels on growth and yield of greengram under custard apple based agri-horti system in Vindhyaan region of Uttar Pradesh. In: Extended Summaries of Third International Agronomy Congress held at IARI, New Delhi, 26-30 November, 609-610. 